Gut, 1963, 4, 223

\title{
Post-necrotic cirrhosis with chronic cholestasis
}

\author{
D. V. DATTA, SHEIlA SHERLOCK, AND PETER J. SCHEUER
}

From the Departments of Medicine and Pathology, Royal Free Hospital, London

EDITORIAL SYNOPSIS Features of biliary obstruction were seen in 57 of 300 cases of post-necrotic cirrhosis but gave rise to real diagnostic difficulty in only 11 cases. The paper deals with the recognition and possible pathogenesis of this syndrome.

The clinical differentiation of post-necrotic cirrhosis from biliary cirrhosis usually presents few problems. Fifty-seven of 300 cases of post-necrotic cirrhosis seen over a period of 20 years showed one or more features of cholestasis (Table I) but could be diag-

\section{TABLE I}

ANALYSIS OF 57 CASES OF POST-NECROTIC CIRRHOSIS WITH SOME FEATURES OF CHOLESTASIS

\begin{tabular}{lc} 
Features of Cholestasis & Number of Cases \\
\hline Pruritus & 14 \\
Xanthomata & 6 \\
High serum alkaline phosphatase $^{1}$ & 38 \\
High serum cholesterol $^{2}$ & 23
\end{tabular}

${ }^{1}$ More than $30 \mathrm{King}-A$ rmstrong units $/ 100 \mathrm{ml}$.

${ }^{2}$ More than $250 \mathrm{mg}$. $/ 100 \mathrm{ml}$.

nosed from biliary cirrhosis without difficulty. In a further 11 patients, however, the prominence of cholestatic features, such as pigmentation, jaundice, xanthelasma, hypercholesterolaemia, and raised serum alkaline phosphatase levels, led to real diagnostic problems. The present paper describes these 11 cases.

\section{MATERIAL AND METHODS}

The cases were investigated clinically, biochemically, radiologically, and surgically to exclude the presence of extrahepatic biliary obstruction. Liver biopsies were assessed by one of us (P.J.S.) without knowledge of clinical details. Necropsies were performed in five cases.

Needle or surgical wedge biopsies of liver were examined from cases 1 to 10 . In cases 4 and 9 two biopsies of different dates were available. Postmortem sections of liver were seen from cases 3,8 , and 11. In all, except the post-mortem section of case 8 , both haematoxylin and eosin and connective tissue preparations were examined.

\section{CLINICAL FINDINGS}

The age of the 11 patients ranged from 27 to 66 years at the time of onset of illness, with a mean of 46 years 6 months (Table II). Symptoms had been present for one to three years before the patients' admission to hospital for investigation. Seven patients were female and four male. None gave a history of excessive alcohol intake or of recent treatment with known hepatotoxic drugs. All reported taking adequate diets.

Previous illnesses included rheumatic heart disease and duodenal ulcer in two patients, and arthritis and sinusitis in one. A definite history of infective hepatitis was elicited from six patients (Table II).

\section{TABLE II}

\begin{tabular}{rr} 
Case No. & $\begin{array}{c}\text { Age at } \\
\text { Illness }\end{array}$ \\
\hline 1 & 63 \\
2 & 32 \\
3 & 66 \\
4 & 54 \\
5 & 33 \\
6 & 52 \\
7 & 45 \\
8 & 49 \\
9 & 27 \\
10 & 27 \\
11 & 64
\end{tabular}

MODE OF PRESENTATION

\begin{tabular}{|c|c|c|c|c|}
\hline $\mathbf{F}$ & + & - & - & + \\
\hline $\mathbf{F}$ & + & - & - & - \\
\hline $\mathbf{F}$ & + & - & - & - \\
\hline $\mathbf{F}$ & - & - & + & + \\
\hline $\mathbf{F}$ & + & + & - & + \\
\hline $\mathbf{F}$ & + & + & - & + \\
\hline $\mathbf{M}$ & + & + & - & - \\
\hline $\mathbf{M}$ & + & - & - & - \\
\hline $\mathbf{M}$ & + & + & - & + \\
\hline $\mathbf{M}$ & + & - & - & - \\
\hline $\mathbf{F}$ & - & + & - & + \\
\hline
\end{tabular}


TABLE III

CLINICAL FEATURES AND FATE

\begin{tabular}{|c|c|c|c|c|c|c|c|c|}
\hline Case No. & Pruritus & Jaundice & Xanthomata & Pigmentation & Fluid Retention & Alive or Dead & Cause of Death & Duration (years) \\
\hline 1 & + & + & - & + & + & $\mathbf{A}$ & & 3 \\
\hline 2 & + & + & + & + & - & $\mathbf{A}$ & & 15 \\
\hline 3 & + & + & - & + & + & D & Coma & 3 \\
\hline 4 & + & + & + & + & + & $\bar{D}$ & Coma & 3 \\
\hline 5 & + & + & - & + & - & $\mathbf{A}$ & & 3 \\
\hline 6 & + & + & + & + & + & D & Coma & 7 \\
\hline 7 & + & + & + & + & - & $\mathbf{A}$ & & 4 \\
\hline 8 & + & + & - & + & + & D & Coma & 2 \\
\hline 9 & + & + & - & + & - & D & Coma & 5 \\
\hline 10 & + & + & - & + & + & $\mathbf{A}$ & & 4 \\
\hline 11 & - & + & - & + & + & D & Post-operative & 1 \\
\hline
\end{tabular}

The disease preceded a diagnosis of cirrhosis by four to 50 years. Hepatitis had in all cases been mild, and had been followed by apparent recovery.

The onset of the chronic illness was always insidious and resembled that of primary biliary cirrhosis (Table II). Five patients presented with pruritus, and a further four with pruritus together with jaundice. One patient presented with jaundice without pruritus and one with xanthelasma.

The chief clinical features during the course of the illness are given in Table III. Pruritus varied in severity and was often sufficiently severe to warrant medication. Intermittent at onset, it became progressively worse and was present at some stage of the illness in 10 of the 11 patients.

Jaundice was usually progressive, but occasionally remittent. In one case (case 2) it was mild. Some degree of jaundice was eventually present in all 11 patients.

Xanthomatous deposits in the skin were observed in four patients, usually in the form of xanthelasma. No definite correlation was found between the presence of xanthomata and the serum cholesterol levels. All patients showed skin pigmentation at some time during the illness. Vascular spiders were seen in eight cases, white nails in two, and finger clubbing in one. Fluid retention was noted in seven patients; all of these were oedematous and in six ascites was also present. In four patients diarrhoea was prominent, and in these steatorrhoea was confirmed biochemically, the total faecal fat varying from 19 to $26 \mathrm{~g}$. per day.

There was marked hepatosplenomegaly in all cases. Portal hypertension was present in seven of the 11 patients, as shown clinically and by barium demonstration of oesophageal varices. In two cases (cases 4 and 6) intrasplenic portal venous pressure was measured and found to be raised. The wedged hepatic vein pressure technique was measured in two (cases 3 and 5) and pressure was raised in one (case 3). Transplenic portal venography was performed in three (cases 3, 4, and 6) and collateral channels were demonstrated. Haematemesis or melaena was noted in four patients; in one of these the bleeding probably came from a peptic ulcer, while in the others the source was thought to be oesophageal varices.

The course of the illness varied considerably. Six patients have died (Table III). In two, hepatocellular failure was precipitated by gastrointestinal haemorrhage, and in one by surgical intervention. No obvious cause for hepatocellular failure was evident in three other patients. Five of the fatal cases gradually developed hepatic precoma and coma in the last months of illness. One patient died after one year, one after two years, two after three years, one after five years, and one after seven years. The surviving five patients have been followed for a period of three to 15 years.

\section{BIOCHEMICAL AND HAEMATOLOGICAL CHANGES}

These are set out in Table IV. The total serum bilirubin levels ranged from 0.4 to $33.0 \mathrm{mg} . / 100 \mathrm{ml}$. Serum alkaline phosphatase levels varied from 16 to 120 King-Armstrong units $/ 100 \mathrm{ml}$. Serum cholesterol levels were also very widely distributed, ranging from 110 to $543 \mathrm{mg} . / 100 \mathrm{ml}$. The level was above $250 \mathrm{mg}$. $/ 100 \mathrm{ml}$. in four of nine patients investigated. Serum albumin varied from 1.8 to $4.0 \mathrm{~g} . / 100 \mathrm{ml}$. and in six cases the level exceeded $3.0 \mathrm{~g} . / 100 \mathrm{ml}$. The serum globulin in nine cases examined was $3.5 \mathrm{~g}$./ $100 \mathrm{ml}$. or more in eight. Electrophoretic analysis of the serum proteins showed an increase in $\beta$ globulin alone in one, $\beta$ and $\gamma$ in four, and $\alpha_{2}, \beta$, and $\gamma$ in one patient. Thymol turbidity varied from 3 to 17 units in 10 patients in whom this investigation was carried out. Serum glutamic oxaloacetic transaminase, measured in six patients, varied from 15 to 210 units per ml.

All patients had a mild normochromic, normocytic anaemia, haemoglobin levels ranging from $10.9 \mathrm{~g}$. to $13.3 \mathrm{~g} . / 100 \mathrm{ml}$. Leucocyte counts varied from 3,500 to 11,000 per c.mm. 
TABLE IV

SERUM BIOCHEMICAL CHANGES ${ }^{1}$

\begin{tabular}{|c|c|c|c|c|c|c|c|c|c|c|c|}
\hline \multirow[t]{2}{*}{ Data } & \multicolumn{11}{|c|}{ Case No. } \\
\hline & 1 & 2 & 3 & 4 & 5 & 6 & 7 & 8 & 9 & 10 & 11 \\
\hline Bilirubin (mg. \%) & $1 \cdot 2$ & $\begin{array}{l}1.0 \\
0.4\end{array}$ & $\begin{array}{r}10.6 \\
5.1\end{array}$ & $\begin{array}{r}16.0 \\
1.0\end{array}$ & $\begin{array}{l}4.8 \\
2.2\end{array}$ & $\begin{array}{r}33.0 \\
1.3\end{array}$ & $\begin{array}{l}4.5 \\
0.6\end{array}$ & $\begin{array}{r}19.9 \\
3.4\end{array}$ & $3 \cdot 2$ & $22 \cdot 0$ & $\begin{array}{r}12 \cdot 5 \\
2 \cdot 1\end{array}$ \\
\hline Alkaline phosphatase (K.-A. units \%) & $\begin{array}{l}52.9 \\
34.5\end{array}$ & $\begin{array}{l}87.0 \\
70.0\end{array}$ & $\begin{array}{l}42.0 \\
35 \cdot 3\end{array}$ & $\begin{array}{l}60.0 \\
20.0\end{array}$ & $\begin{array}{l}120.0 \\
105.0\end{array}$ & $\begin{array}{l}42^{2} \\
23^{2}\end{array}$ & $\begin{array}{l}42.0 \\
18.0\end{array}$ & $\begin{array}{l}55.0 \\
16.0\end{array}$ & $17 \cdot 0$ & 43.0 & $\begin{array}{l}37.5 \\
29.0\end{array}$ \\
\hline Cholesterol (mg. \%) & 163 & $\begin{array}{l}295 \\
264\end{array}$ & 238 & $\begin{array}{l}443 \\
332\end{array}$ & $\begin{array}{l}344 \\
291\end{array}$ & $\begin{array}{l}543 \\
110\end{array}$ & $\begin{array}{l}220 \\
130\end{array}$ & & & 117 & 138 \\
\hline Albumin (g. \%) & $3 \cdot 4$ & $\begin{array}{l}3 \cdot 3 \\
2 \cdot 8\end{array}$ & $\begin{array}{l}3.2 \\
1.9\end{array}$ & $\begin{array}{l}3 \cdot 1 \\
2 \cdot 6\end{array}$ & $\begin{array}{l}4 \cdot 0 \\
3 \cdot 2\end{array}$ & $\begin{array}{l}3.4 \\
2.8\end{array}$ & $\begin{array}{l}3.0 \\
2.6\end{array}$ & $\begin{array}{l}2.4 \\
1.8\end{array}$ & & & $2 \cdot 7$ \\
\hline Globulin (g. \%) & 3.9 & $\begin{array}{l}6 \cdot 2 \\
5.8\end{array}$ & $\begin{array}{l}4.6 \\
3.7\end{array}$ & $\begin{array}{l}2 \cdot 6 \\
2 \cdot 1\end{array}$ & $\begin{array}{l}5.4 \\
4 \cdot 4\end{array}$ & $\begin{array}{l}6 \cdot 1 \\
4 \cdot 4\end{array}$ & $\begin{array}{l}5.5 \\
4.0\end{array}$ & $\begin{array}{l}3.7 \\
3.5\end{array}$ & & & $4 \cdot 2$ \\
\hline Protein electrophoresis & & $\beta \gamma$ & $\beta \gamma$ & $\beta \gamma$ & $\beta$ & $\beta \gamma$ & $\alpha_{2} \beta \gamma$ & & & & \\
\hline G.O. transaminase (units/ml.) & & & & 15 & $\begin{array}{l}62 \\
49\end{array}$ & $\begin{array}{r}146 \\
56\end{array}$ & $\begin{array}{r}210 \\
68\end{array}$ & $\begin{array}{r}100 \\
55\end{array}$ & & 58 & \\
\hline
\end{tabular}

${ }^{1}$ Highest and lowest values recorded in case of repeated determinations ${ }^{2}$ Bodansky units \%

TABLE V

HISTOLOGICAL FINDINGS

Features Case and Specimen Number

\begin{tabular}{llllllllllllllll}
\hline 1 & 2 & $3 a$ & $3 b$ & $4 a$ & $4 b$ & 5 & 6 & 7 & $8 a$ & $8 b$ & $9 a$ & $9 b$ & 10 & 11 &
\end{tabular}

\begin{tabular}{|c|c|c|c|c|c|c|c|c|c|c|c|c|c|c|c|}
\hline Specimen & Needle & Needle & Needle & Necropsy & Needle & Needle & Needle & Needle & Needle & Needle & Necropsy & Needle & Needle & Wedge & Necropsy \\
\hline Fibrosis & + & + & + & + & + & + & + & + & + & + & + & + & + & + & + \\
\hline Nodules & + & + & + & + & + & - & + & + & - & + & + & - & + & + & + \\
\hline Lobules & + & + & - & + & + & - & + & - & + & - & + & - & + & + & + \\
\hline $\begin{array}{l}\text { Collapse } \\
\text { Sinusoidal }\end{array}$ & + & + & - & + & + & - & - & + & - & - & + & - & + & + & + \\
\hline varices & + & - & - & + & + & - & - & + & - & + & + & + & + & + & + \\
\hline Inflammation & + & + & + & + & + & + & + & + & + & + & + & + & + & + & + \\
\hline $\begin{array}{l}\text { Bile ducts } \\
\text { Ductular pro- }\end{array}$ & - & + & - & + & + & - & - & + & - & + & + & + & - & + & + \\
\hline liferation & + & + & + & + & + & + & + & + & + & + & + & + & + & + & + \\
\hline Cholangitis & - & - & - & - & - & - & - & + & - & - & - & - & - & + & - \\
\hline Bile stasis & - & - & + & + & + & + & - & - & - & + & + & + & + & - & + \\
\hline Cell necrosis & + & + & + & + & + & + & + & + & + & + & + & + & + & + & + \\
\hline Fatty change & - & - & - & + & - & - & - & - & - & - & - & - & - & - & - \\
\hline $\begin{array}{c}\text { Histological } \\
\text { diagnosis }\end{array}$ & $\begin{array}{l}\text { Post- } \\
\text { necrot. } \\
\text { cirr- } \\
\text { hosis }\end{array}$ & $\begin{array}{l}\text { Post- } \\
\text { necrot. } \\
\text { cirr- } \\
\text { hosis }\end{array}$ & $\begin{array}{l}\text { Post- } \\
\text { necrot. } \\
\text { cirr- } \\
\text { hosis }\end{array}$ & $\begin{array}{l}\text { Post- } \\
\text { necrot. } \\
\text { cirr- } \\
\text { hosis }\end{array}$ & $\begin{array}{l}\text { Post- } \\
\text { necrot. } \\
\text { cirr- } \\
\text { hosis }\end{array}$ & $\begin{array}{l}\text { Post- } \\
\text { necrot. } \\
\text { cirr- } \\
\text { hosis }\end{array}$ & $\begin{array}{l}\text { Juve- } \\
\text { nile } \\
\text { cirr- } \\
\text { hosis }\end{array}$ & $\begin{array}{l}\text { Post- } \\
\text { necrot. } \\
\text { cirr- } \\
\text { hosis }\end{array}$ & $\begin{array}{l}\text { Juve- } \\
\text { nile } \\
\text { cirr- } \\
\text { hosis }\end{array}$ & $\begin{array}{l}\text { Post- } \\
\text { necrot. } \\
\text { cirr- } \\
\text { hosis }\end{array}$ & $\begin{array}{l}\text { Post- } \\
\text { necrot. } \\
\text { cirr- } \\
\text { hosis }\end{array}$ & $\begin{array}{l}\text { Post- } \\
\text { necrot. } \\
\text { cirr- } \\
\text { hosis }\end{array}$ & $\begin{array}{l}\text { Post- } \\
\text { necrot. } \\
\text { cirr- } \\
\text { hosis }\end{array}$ & $\begin{array}{l}\text { Post- } \\
\text { necrot. } \\
\text { cirr- } \\
\text { hosis }\end{array}$ & $\begin{array}{l}\text { Post- } \\
\text { necrot. } \\
\text { cirr- } \\
\text { hosis }\end{array}$ \\
\hline
\end{tabular}

HISTOLOGICAL FINDINGS

The histological features are recorded in Table $\mathrm{V}$. Where two specimens were examined from any patient these are designated $a$ and $b$.

Sections of all cases showed fibrosis, usually coarse (Figs. 1 to 3 ), and nodule formation was present in all except case 7 . Regenerative activity was noted in the nodules and liver cell plates were often several cells thick. In all cases except 5 and 7 there was evidence of previous collapse (Figs. 2 and 3 ), a definitive feature of post-necrotic or post-collapse cirrhosis. Inflammatory infiltration was generally slight or moderate in degree, but heavy in specimens 3b, 7, and 9a. Lymphocytes predominated, neutrophil infiltration was usually slight, and eosinophils, when present, were scanty. Plasma cells were abundant in cases 5 and 7 and were seen in smaller numbers in other sections. Fibroblastic activity was not marked, and fibrous tissue was usually dense and mature. Bile ducts of interlobular calibre were not always seen, but this may have been due partly to the small size of some samples. Active inflammation around interlobular bile ducts sometimes observed in biliary cirrhosis (Moschcowitz, 1952) was not a prominent feature. In case 3 there was a minor degree of peribiliary fibrosis, and in case 10 there was occasional concentric peribiliary infiltra- 


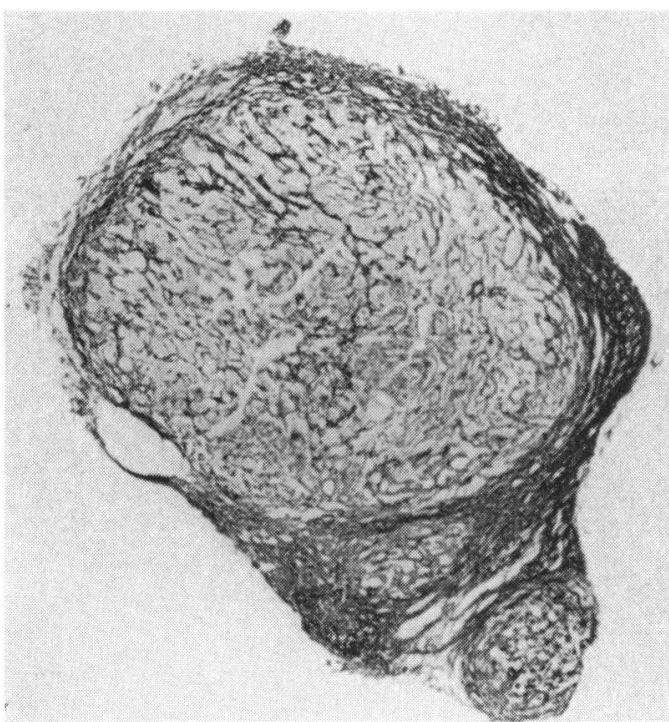

FIG. 1

FIG. 1. Case 8. Needle liver biopsy showing postnecrotic cirrhosis. Regeneration nodules of varying size are present and there is fibrosis. Silver impregnation, original magnification $\times 40$.

FIG. 2. Case 8. Necropsy liver section showing post-necrotic cirrhosis. There is nodule formation, extensive fibrosis, and evidence of previous collapse. Haematoxylin and eosin stain, original magnification $\times 40$.

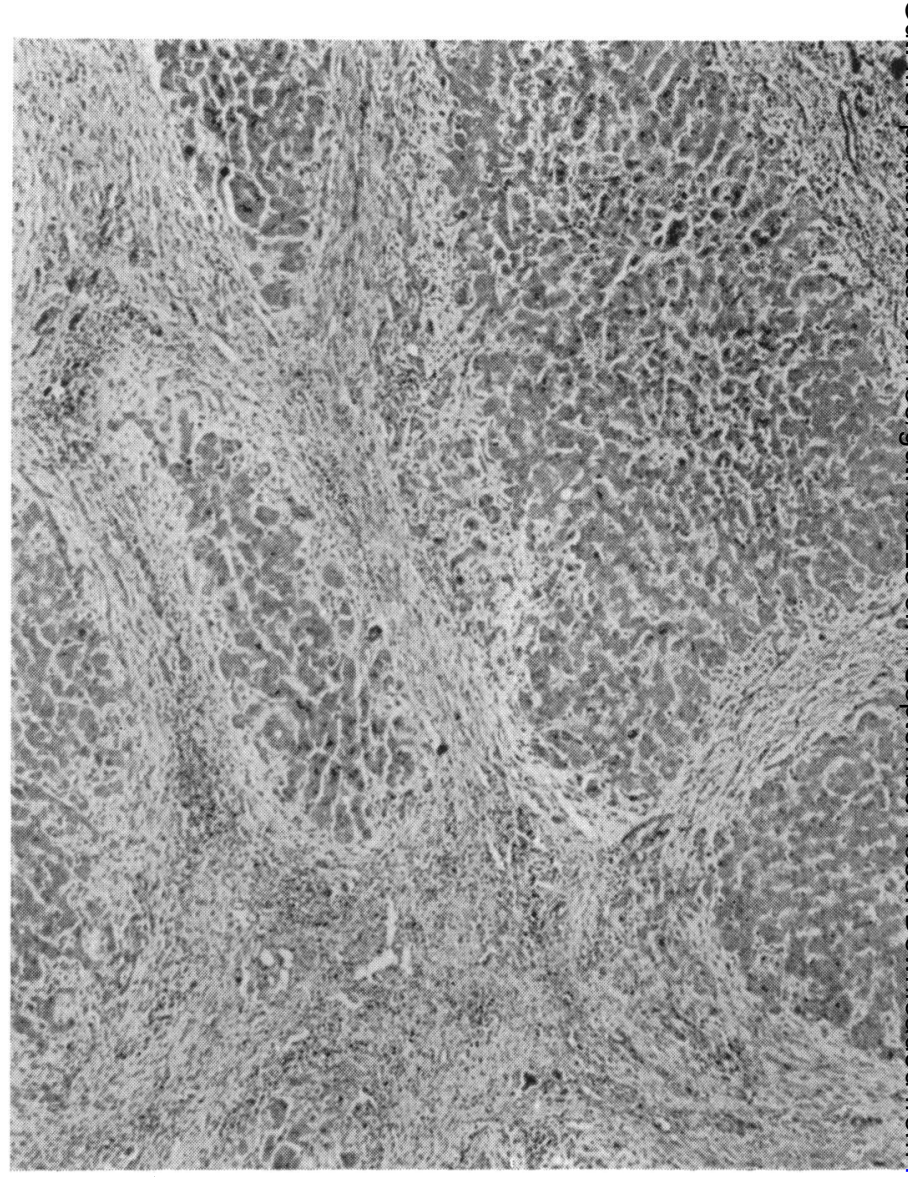

FIG. 2 


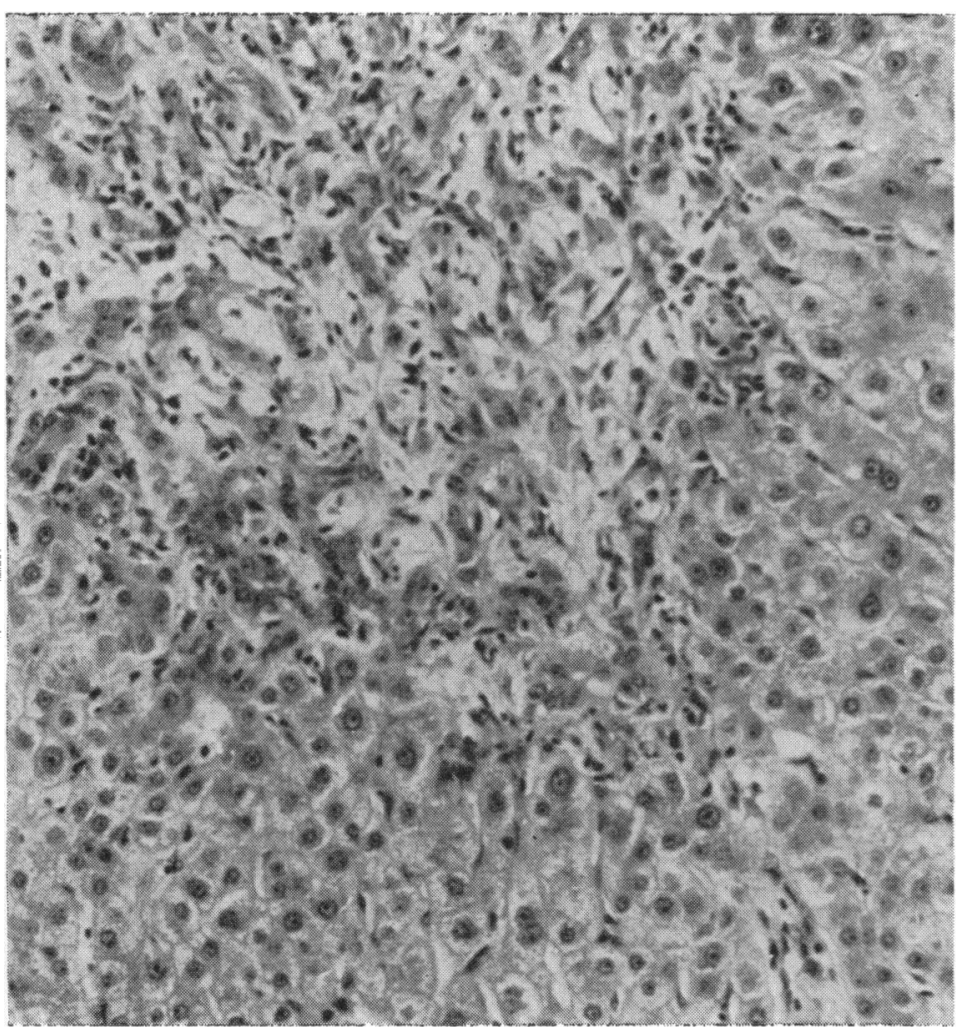

FIG. 4

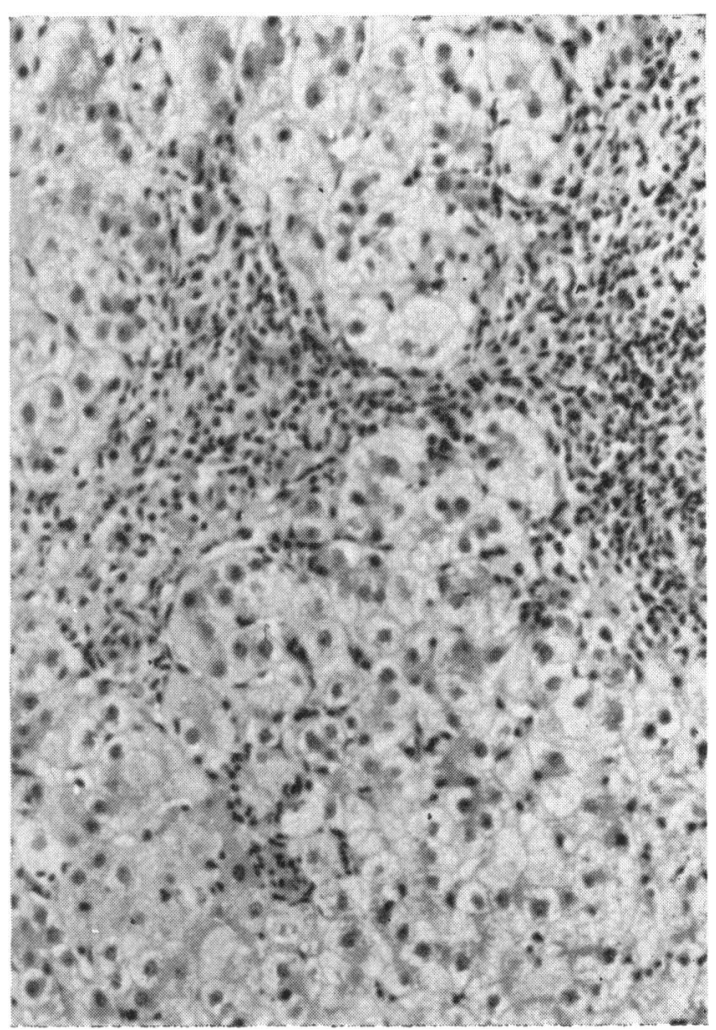

FIG. 6

FIG. 4. Case 10. Wedge liver biopsy. Proliferation of bile ductules is seen in the portal zone, and inflammatory infiltration in the portal zone and adjacent parenchyma. These features are common in biliary obstruction, but the overall appearances in this case are those of post-necrotic cirrhosis, as shown in Figure 5. Haematoxylin and eosin stain, original magnification $\times 160$.

FIG. 6. Case 7. Needle liver biopsy showing 'juvenile' cirrhosis. Note the extensive inflammation in portal areas and parenchyma, and the atypical liver cell plates. Plasma cells are abundant. Haematoxylin and eosin stain, original magnification $\times 160$.

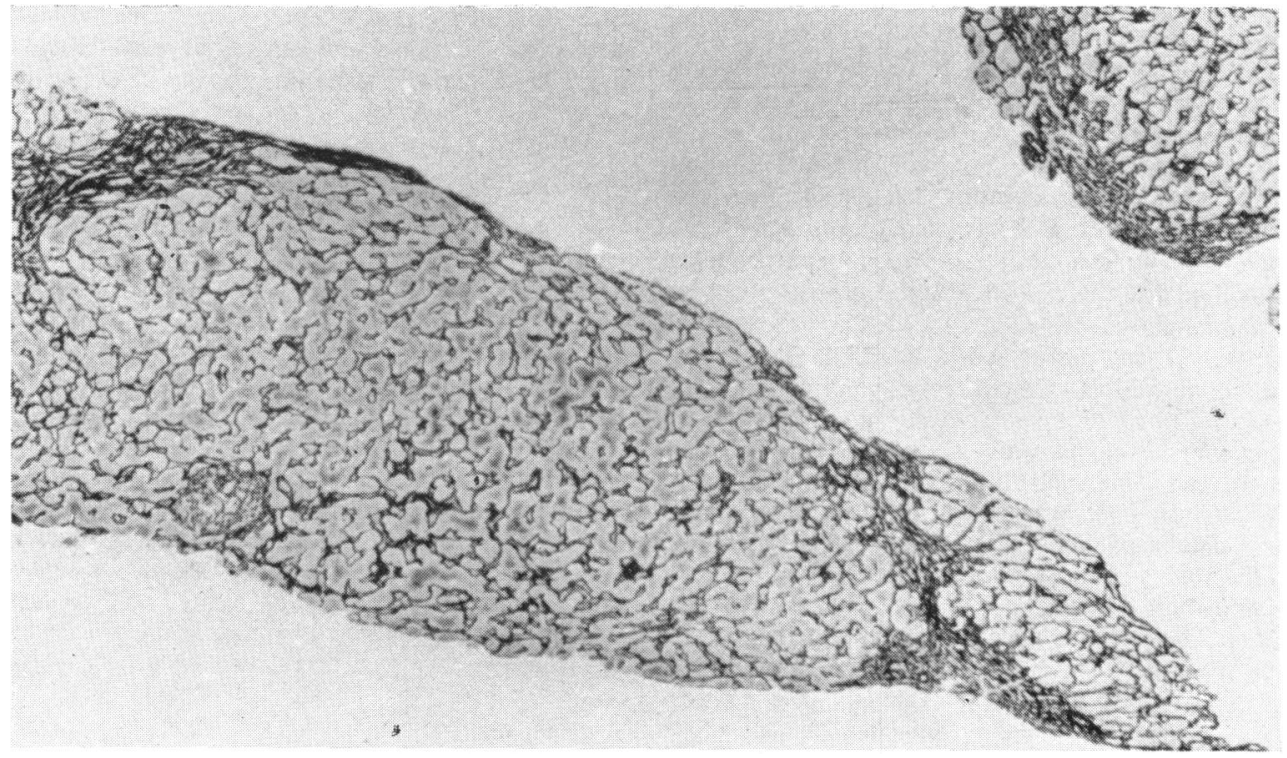

FIG. 5. Case 7. Needle liver biopsy showing 'juvenile' cirrhosis. Lobular architecture is distorted and the liver is intersected by connective tissue bands. Silver impregnation, original magnification $\times 40$ 
tion with mononuclear cells. Bile ductular proliferation (Fig. 4) was present in all specimens and was often considerable. Features of cholangitis were seen in sections of cases 6 and 10. Bile stasis was seen in the form of bile thrombi or intracellular pigment in five cases. In case 3 the bile stasis was most marked near the junction of fibrous tissue and parenchyma, while in the others it was scattered. In case 8 small amounts of bile were seen in bile ducts. Liver cell degeneration was generally slight, as was the fatty change in case 3.

The histological interpretation of the material from cases 5 and 7 was that of an active 'juvenile cirrhosis' or 'cirrhosis of young people' (Harrison, Read, and Sherlock, 1961) (Figs. 5 and 6) and the remaining cases were considered to be examples of post-necrotic cirrhosis.

\section{EXAMPLES OF CASES}

CASE 4 This 56-year-old housewife was admitted to hospital in August 1957 with xanthelasma of two years' duration. A past history of rheumatic heart disease and of infective hepatitis $\mathbf{4 8}$ years previously was elicited. On examination, skin pigmentation, oedema, scratch marks, jaundice, and spider naevi were noted. Both liver and spleen were enlarged. Oesophageal varices were detected radiologically and a splenic venogram showed collateral veins. The intrasplenic pressure was $30 \mathrm{~mm}$. $\mathrm{Hg}$. The haemoglobin level was $12.3 \mathrm{~g} . / 100 \mathrm{ml}$.; white blood cell count 5,000 per c.mm.; serum bilirubin $1.0 \mathrm{mg} . / 100 \mathrm{ml}$.; serum cholesterol $332 \mathrm{mg} .100 \mathrm{ml}$.; serum alkaline phosphatase $33 \mathrm{~K}$.-A. units $/ 100 \mathrm{ml}$.; thymol turbidity 2.5 to 4 units; serum albumin $3.1 \mathrm{~g}$. $/ 100 \mathrm{ml}$. and serum globulin $2.6 \mathrm{~g} .1100 \mathrm{ml}$. Bromsulphalein retension $(5 \mathrm{mg}$. per $\mathrm{kg}$. body weight) was $36 \%$ at 35 minutes.

The patient was readmitted in March 1958 with severe haematemesis. Examination at this time showed deepening of jaundice, palmar erythema, oedema, and ascites. The serum bilirubin level was $7.6 \mathrm{mg} . / 100 \mathrm{ml}$. and reached $16.0 \mathrm{mg} .100 \mathrm{ml}$. in the terminal stage. Serum cholesterol was $443 \mathrm{mg} . / 100 \mathrm{ml}$., serum alkaline phosphatase ranged from 20 to $60 \mathrm{~K}$.-A. units $/ 100 \mathrm{ml}$., serum G.O. transaminase was 15 units $/ \mathrm{ml}$., serum albumin $2 \cdot 6 / 100 \mathrm{ml}$. and serum globulin $2 \cdot 1 \mathrm{~g} . / 100 \mathrm{ml}$. The patient was treated with a Sengstaken oesophageal tube and intravenous pitressin but developed hepatocellular failure and died four weeks later. At necropsy a coarse post-necrotic cirrhosis was seen.

Needle liver biopsy performed in March 1958 showed the presence of a post-collapse type of cirrhosis with broad mature fibrous areas containing approximated portal structures. Regeneration nodules of varying size were present and lobular structure was only preserved in a few places. Inflammatory infiltration was moderate in degree and chiefly mononuclear in type. Bile stasis was slight. There was considerable proliferation of bile ductules, and these extended for a short distance into the parenchyma. The margins of the latter were irregular. A further biopsy provided only a very small amount of liver tissue. In this, inflammatory infiltration was less marked.

Features of cholestasis, such as pruritus, xanthelasma, skin pigmentation, and high serum alkaline phosphatase and cholesterol levels, were present. The necropsy and needle biopsy findings were nevertheless those of a post-necrotic rather than a biliary cirrhosis.

CASE 5 This Greek housewife aged 35 years presented in August 1957 with itching and jaundice of two years' duration. Examination showed jaundice, pigmentation, and hepatomegaly, and scratch marks were seen on the skin. The serum bilirubin level was $4.8 \mathrm{mg} . / 100 \mathrm{ml}$. A diagnosis of obstructive jaundice was made but, at laparotomy, no lesion of the biliary tree was found. Jaundice and pruritus persisted after operation. In October 1958 she was again admitted. At this time the physical signs were unchanged. Laboratory investigations showed a haemoglobin level of $11.0 \mathrm{~g} . / 100 \mathrm{ml}$. and a mean cell haemoglobin concentration of $30 \%$. A blood film showed anisocytosis. The white blood cell count was 6,100 per c.mm.; platelets 166,000 per c.mm.; serum bilirubin level 2.2 to $2.5 \mathrm{mg}$. $100 \mathrm{ml}$.; alkaline phosphatase $120 \mathrm{~K}$.-A. units $/ 100 \mathrm{ml}$.; serum cholesterol 291 to 344 $\mathrm{mg} . / 100 \mathrm{ml}$; thymol turbidity 7 units; serum albumin 4.0 g. $/ 100 \mathrm{ml}$.; serum globulin $4.4 \mathrm{~g} . / 100 \mathrm{ml}$.; serum G.O. transaminase 49 to 62 units $/ \mathrm{ml}$; ; prothrombin time 12 seconds, and bromsulphalein retention $(5 \mathrm{mg}$. per $\mathrm{kg}$. body weight) $45 \%$ at 30 minutes. Faecal occult blood tests were negative. Radiographs of the chest and hand showed only some loss of bone density. The wedged hepatic venous pressure was 8 to $12 \mathrm{~mm}$. $\mathrm{Hg}$, which is within normal limits.

Sections of a liver biopsy performed in November 1958 showed nodular cirrhosis with broad and narrow fibrous septa demarcating small regeneration nodules. A heavy mixed inflammatory infiltrate, including many plasma cells and some fibroblasts, was present in the septa and extended into the adjacent parenchyma. There was no detectable bile stasis and only slight proliferation of bile ductules. Liver cells were large and pale-staining.

The clinical features suggested obstructive jaundice. No obstruction was, however, found on laparotomy, and the histological findings were those of an active cirrhosis of 'juvenile' type.

CASE 6 This 52-year-old Hungarian housewife was admitted to hospital in December 1954 complaining of jaundice, itching, and fatigue. She had had infective hepatitis five years previously. Examination showed jaundice, skin pigmentation, xanthelasma, hepatosplenomegaly, and scratch marks on the skin. Laboratory investigations showed a serum bilirubin level of $1.3 \mathrm{mg}$./ $100 \mathrm{ml}$., a serum alkaline phosphatase level of 23 to 42 Bodansky units $/ 100 \mathrm{ml}$, and a serum cholesterol level of $543 \mathrm{mg} . / 100 \mathrm{ml}$. She was treated with rest and diet with some improvement in her clinical condition. In 1955 laparotomy was performed because of progressive 
jaundice, but no obstruction to the biliary tree was found, and symptoms and signs persisted after operation. Cortisone was given with little improvement. Postoperatively the serum alkaline phosphatase level was 23 Bodansky units $/ 100 \mathrm{ml}$., serum bilirubin level $3.1 \mathrm{mg}$. $100 \mathrm{ml}$., and serum cholesterol level $178 \mathrm{mg} . / 100 \mathrm{ml}$. A diagnosis of primary biliary cirrhosis was considered. In May 1958, a severe haematemesis required transfusion. Laboratory investigations at this time showed a haemoglobin level of $12.6 \mathrm{~g} . / 100 \mathrm{ml}$; white blood cell count 6,000 per c.mm.; serum bilirubin $1.8 \mathrm{mg} . / 100 \mathrm{ml}$.; serum cholesterol $233 \mathrm{mg} . / 100 \mathrm{ml}$.; alkaline phosphatase $63 \mathrm{~K}$.-A. units $/ 100 \mathrm{ml}$; ; prothrombin time 14.5 seconds; serum albumin $3.4 \mathrm{~g} . / 100 \mathrm{ml}$. and serum globulin $4.4 \mathrm{~g}$. $/$ $100 \mathrm{ml}$. Oesophageal varices were demonstrated radiologically. A transplenic venogram showed collateral vessels, and the intrasplenic pressure was $26 \mathrm{~mm}$. $\mathrm{Hg}$. Further haematemeses in February and July 1960 were followed by the development of ascites, signs of hepatic precoma, and deepening jaundice. The serum bilirubin reached $33 \mathrm{mg} . / 100 \mathrm{ml}$; the serum cholesterol fell to $110 \mathrm{mg} . / 100 \mathrm{ml}$., serum G.O. transaminase rose to 146 units $/ \mathrm{ml}$., serum albumin fell to $2 \cdot 8 \mathrm{~g} . / 100 \mathrm{ml}$. and serum globulin rose to $6.1 \mathrm{~g} . / 100 \mathrm{ml}$. Her condition gradually deteriorated and she died at home in July 1960. Necropsy was not carried out.

Sections of a liver biopsy done in June 1958 showed the presence of cirrhosis. Broad septa of partly mature fibrous tissue surrounded regeneration nodules, and there was evidence of previous collapse. Moderately heavy inflammatory infiltration, chiefly with mononuclear cells, was seen. Some proliferated bile ducts were associated with local accumulations of inflammatory cells. No bile stasis was detected. There was a considerable degree of liver cell degeneration.

The clinical features were typical of biliary obstruction, but no obstruction was found at laparotomy. The needle biopsy findings were those of post-necrotic cirrhosis.

\section{DISCUSSION}

Biliary obstruction may occur in a variety of chronic liver diseases other than extrahepatic biliary obstruction and primary biliary cirrhosis. Cholestasis complicating the chronic liver disease of alcoholics is well recognized (Leevy, Zinke, White, and Gnassi, 1953; Popper, Szanto, Steigmann, Terry, Dolaz, and Buckingham, 1953; Phillips and Davidson, 1954 and 1957; Zieve, 1958; Ballard, Bernstein, and Farrar, 1961), usually as transient episodes of jaundice related to excessive alcohol intake (Phillips and Davidson, 1957; Zieve, 1958; Ballard et al., 1961). These may lead to surgical exploration (Phillips and Davidson, 1954 and 1957; Zieve, 1958). The present patients, were, however not alcoholics and fatty change was rare and slight in the biopsy material.
The onset of symptoms in the present cases was gradual and not usually related to recent infective hepatitis. The mode of onset, failure of obstructive symptoms to clear within a few months, and the histological findings distinguish them from patients with hepatitis having a prolonged obstructive course (Shaldon and Sherlock, 1957; Dubin, Sullivan, LeGolvan, and Murphy, 1960).

Obstruction to the extrahepatic biliary tree was excluded in all 11 patients. The remaining problem therefore lay chiefly in the distinction of postnecrotic from primary biliary cirrhosis. The morphological features of different types of cirrhosis enable a diagnosis to be made on histological examination in most instances in which adequate material is available. Problems may, however, arise when only small needle biopsies are examined or when the cirrhosis has reached a late stage. Moschcowitz (1952) stated that the end stage of biliary cirrhosis differed little from that of Laennec's cirrhosis. MacMahon (1958) observed that the typical picture of biliary cirrhosis was greatly altered in the late stages, so that, unless earlier biopsy material was available, histological diagnosis might be uncertain.

In the present series the defining features of postnecrotic cirrhosis were clearly seen in nine of the 11 cases, in spite of the fact that in many of them the amount of material examined was small. In the remaining two cases the appearances suggested a 'juvenile' type of cirrhosis (Harrison et al., 1961). In one of these (case 5) nodular cirrhosis was present, while in the other the presence of true regeneration nodules was doubtful. The typical histological picture of primary biliary cirrhosis was not present in any of the 11 cases.

Two possible explanations for an association of post-necrotic cirrhosis with clinical features of biliary obstruction must be considered. First, some of the cases may be examples of primary biliary cirrhosis in a late stage. Features of biliary cirrhosis such as bile ductular proliferation, extension of ductules into the parenchyma, and bile stasis and liver cell degeneration at the margins of the parenchyma were occasionally observed, but these may all occur in post-necrotic cirrhosis (Steiner, 1960). The clinical history of the patients suggests that this explanation is probably not applicable in the present instance, since biopsies were usually done within a year or two of onset of the chronic illness.

Secondly, the cases might be examples of postnecrotic cirrhosis, in which obstruction to the intrahepatic biliary tree has resulted from fibrosis or nodular regeneration. Since 57 of 300 cases of postnecrotic cirrhosis showed one or more clinical features of biliary obstruction (Table 1), an obstructive component seems to be more common in 
this disease than is generally recognized. We believe that the 11 cases described represent extreme examples of such obstruction developing in the course of post-necrotic cirrhosis.

The clinical differentiation of these cases from primary biliary cirrhosis and from extrahepatic biliary obstruction can be difficult. Laparotomy may be unavoidable in some patients, but this procedure is potentially hazardous and may, as in one of the present cases, precipitate hepatic coma. Careful clinical observation and full investigation, including aspiration liver biopsy, should however enable a correct diagnosis to be reached in most instances. Percutaneous cholangiography is a helpful preliminary to surgical exploration (Shaldon, Barber, and Young, 1962).

The prognosis of the condition described is not good; six of the 11 patients died. The mean duration of illness in the fatal cases was three years and six months. The commonest cause of death was hepatocellular failure. The prognosis was comparable to Klatskin's (1958) series of post-necrotic cirrhosis due to anicteric hepatitis in which he observed that five of nine patients died within five and a half to 55 months of the onset of illness. The prognosis when compared to that of primary biliary cirrhosis in terms of mean duration of illness before death was relatively bad; in a series of 23 fatal cases of primary biliary cirrhosis the mean duration of illness was five years and five months (Sherlock, 1959).

\section{SUMMARY AND CONCLUSIONS}

Features of biliary obstruction were seen in 57 of 300 cases of post-necrotic cirrhosis, but gave rise to real diagnostic difficulty in only eleven. In these the clinical course and biochemical features, such as skin pigmentation, pruritus, deep jaundice, xanthomata, and high serum cholesterol and alkaline phosphatase levels suggested biliary obstruction. The histological features, however, were those of post-necrotic cirrhosis in nine patients and of active 'juvenile' cirrhosis in two. Possible explanations for this syndrome are discussed, and it is considered that obstruction to the intrahepatic biliary tree may have occurred as the result of the cirrhosis.
Laparotomy may be hazardous in such cases and needle liver biopsies are essential in diagnosis.

The illness was progressive. Portal hypertension and fluid retention developed in seven patients. Six patients died, the commonest cause of death being hepatocellular failure. The mean duration of illness in the fatal cases was three years and six months. The prognosis was comparable to that of postnecrotic cirrhosis but unfavourable when compared with that of primary biliary cirrhosis.

We wish to thank Professor J. H. Dible and Professor C. V. Harrison for allowing us access to histological material, and to Professor K. R. Hill for valuable advice. The work was supported by a grant from the Countess Peel Research Fund to one of us (D. V. Datta), and the Irwin Strasburger Memorial Medical Foundation helped with expenses.

\section{REFERENCES}

Ballard, H., Bernstein, M., and Farrar, J. T. (1961). Fatty liver presenting as obstructive jaundice. Amer. J. Med., 30, 196-201.

Dubin, I. N., Sullivan, B. H. Jr., LeGolvan, P. C., and Murphy, L. C. (1960). The cholestatic form of viral hepatitis. Ibid., 29, 55-72.

Harrison, C. V., Read, A. E. A., and Sherlock, S. (1961). Progressive 'juvenile' cirrhosis. Quart. J. Med., 30, 410-412.

Klatskin, G. (1958). Subacute hepatic necrosis and post-necrotic cirrhosis due to anicteric infections with the hepatitis virus. Amer. J. Med., 25, 333-358.

Leevy, C. M., Zinke, M. R., White, T. J., and Gnassi, A. M. (1953). Clinical observations on the fatty liver. Arch. intern. Med., 92, 527-541.

MacMahon, H. E. (1958). Biliary cirrhosis. Ibid., 102, 841-846.

Moschcowitz, E. (1952). Morphology and pathogenesis of biliary cirrhosis. Arch. Path., 54, 259-275.

Phillips, G. B., and Davidson, C. S. (1954). Acute hepatic insufficiency of the chronic alcoholic. Clinical and pathological study. Arch. intern. Med., 94, 585-603.

, - (1957). Liver disease of the chronic alcoholic simulating extrahepatic biliary obstruction. Gastroenterology, 33, 236-244.

Popper, H., Szanto, P. B., Steigmann, F., Terry, R. B., Dolaz, E., and Buckingham, W. B. (1953). Fatty liver with jaundice. Clinical-pathologic correlation of an entity. Proc. Inst. Med. Chic., 19, 307.

Shaldon, S., Barber, K. M., and Young, W. B. (1962). Percutaneous transhepatic cholangiography - a modified technique. Gastroenterology, 42, 371-379.

-, and Sherlock, S. (1957). Virus hepatitis with features of prolonged bile retention. Brit. med. J., 2, 734-738.

Sherlock, S. (1959). Primary biliary cirrhosis (chronic intrahepatic obstructive jaundice). Gastroenterology, 37, 574-586.

Steiner, P. E. (1960). Precision in the classification of cirrhosis of the liver. Amer. J. Path., 37, 21-47.

Zieve, L. (1958). Jaundice, hyperlipemia and hemolytic anaemia: a heretofore unrecognized syndrome associated with alcoholic fatty liver and cirrhosis. Ann. intern. Med., 48, 471-496. 